\title{
Tenderisation of Meat by Bromelain Enzyme Extracted from Pineapple Wastes
}

\author{
Thangjam Anand Singh ${ }^{1}$, Prakash K. Sarangi ${ }^{1}$ and Ngankham Joykumar Singh ${ }^{2 *}$ \\ ${ }^{1}$ AICRP (PHET), Directorate of Research, ${ }^{2}$ Department of Agriculture Engineering, College \\ of Agriculture, Central Agricultural University, Iroisemba, Imphal - 795 004, India
}

*Corresponding author

\begin{tabular}{|l|}
\hline Ke y w o r d s \\
Pineapple waste, \\
$\begin{array}{l}\text { Bromelain, Meat, } \\
\text { Tenderization }\end{array}$ \\
\hline Article Info \\
\hline $\begin{array}{l}\text { Accepted: } \\
\text { 24 August } 2018 \\
\text { Available Online: } \\
\text { 10 September } 2018\end{array}$ \\
\hline
\end{tabular}

\section{Introduction}

The most common quality characteristics of meat are the Toughness which is due to the presence of intramuscular connective tissue, intramuscular fat and the length of the sarcomere (Kemp et al., 2010, Sunantha Ketnawa \& Saroat Rawdkuen 2011).
In the present investigation the extraction of bromealin enzyme from four different pineapple wastes (Peel, stem, core and crown) and its effect for tenderization of chicken and beef meats were studied. About $60 \%$ of pineapple fruit was treated as wastes and peel accounts the maximum sharing of $30 \%$ of total wastes. The characteristics of crude bromealin in form of $\mathrm{pH}$, TSS, total protein content and total activity were studied. The TSS $\left(7^{0}\right.$ Brix) and $\mathrm{pH}(5.0)$ of core and stem showed the maximum values respectively. Crown portion showed the maximum total protein content and bromelain activity of 239 $\mathrm{mg}$ and $184.69 \mathrm{umol} / \mathrm{min} / \mathrm{ml}$ respectively. The physio-chemical and quality characteristics like water-holding capacity, cooking yield, $\mathrm{pH}$, moisture content and TCA-soluble peptides content of the bromelain enzyme (BE) treated meats were conducted. Four different types of bromelain treatments like $0.3 \%, 0.7 \%, 1.0 \%$ and $2.0 \%$ were studied along with control. In both the meats moisture content, $\mathrm{pH}$, cooking yield and water holding capacity were decreased as the percentage of BE treatments increased having highest in controlled condition. Results indicated that as the concentration of $\mathrm{BE}$ was increased, the TCA soluble peptide contents were also increased. The highest TCA soluble peptide $(798 \mu \mathrm{mol} / \mathrm{g})$ of were observed in the chicken $20 \%$ treated followed by beef ( 709 $\mu \mathrm{mol} / \mathrm{g}) 20 \%$ treated. The lowest TCA soluble fractions were that of the beef without any treatment with $238 \mu \mathrm{mol} / \mathrm{g}$. The texture profile of BE treated meats were also studied which indicates gradual changes in the meat texture with increase of $\mathrm{BE}$ concentrations. 
improve the qualities of meat. Apart from the pressure treatments, electrical stimulation and blade tenderization (Pietrasik, 2010), treatment by proteolytic enzymes is a popular method for meat tenderization. Proteolytic enzymes derived from different sources have been widely usedglobally as meat tenderizer. Plant originated proteolytic enzymes are considered better as compared to the bacterial derived enzymes because of safety problems like pathogenicity or other harmful effects (Chen et al., 2006).

The pineapple (Ananascomosus) is the most important horticultural produce of the family Bromeliaceae. About more than $40 \%$ of the total pineapple production of the country was made from the NE region and 90 to $95 \%$ of the produce is organic. 'Kew' and 'Queen' are the common cultivars grown this region. Manipur contributes about $7.37 \%$ of the total pineapple production of India with productivity of $9.5 \mathrm{MT} / \mathrm{HA}$ having a production of $124146.00 \mathrm{MT}$. It has been calculated that about 50,000-60,000 MT of pineapple wastes are produced annually causing great environmental pollution.

During pineapple processing, the crown and stem are cut off before peeling. The core is then removed for further processing. These wastes (peel, core, stem, crown and leaves) generally account for $60 \%(\mathrm{w} / \mathrm{w})$ of total pineapple weight The increasing production of pineapple processed items, results in massive waste generations mainly due to the elimination of components unsuitable for human consumption. These wastes are usually prone to microbial spoilage thus limiting further exploitation. Further, the Drying, storage and shipment of these wastes is cost effective and hence efficient, inexpensive and eco-friendly utilization is becoming more and more necessary. The utilization of waste would be an innovation to handle the great deal of waste from processing. Owing to the above facts, the biotechnological approaches for efficient use of lignocellulosic materials like pineapple by-products having enormous availability in NE region may be focused as cheap sources of Bromelain enzyme. Bromelain has found applications as antiinflammatory, antithrombotic, fibrinolytic activities and anticancer agent.

Pineapple wastes are found to have prospective uses as raw materials that can be converted into value-added products. As wastes, these can be utilized as a fertilizer or animal feed. The peel portion is rich in cellulose, hemicelluloses and other carbohydrates that can be used to produce paper, banknotes, and cloth (Bartholomew et al., 2003). The production of frozen pineapple juice concentrates can be possible for alcoholic beverages (Thanong, 1985). Pineapple wastes have been used as a nutrient substance in culture broth (Nigam, 1998) and cellulose production (Omojasola et al., 2008). Many value added compounds like methane, ethanol, citric acid and antioxidant compounds are also produced from the pineapple wastes (Tanaka et al., 1999; Nigam, 1999; Chau and David, 1995; Kumar et al., 2003; Imandi et al., 2008). Pineapple wastes are also acting as a source of bioactive compounds called bromelain (Ketnawa et al., 2010; Rolle, 1998; Schieber et al., 2001). Pineapple wastes are the good sources of bromelain (SmithMarshall and Golden 2012). It was identified for the first time by Marcano in 1891 (Upadhyay et al., 2010). Since 1894 (Neta et al., 2012), the isolation of bromelain has been started

The application of bromelain has been extended commercially in the food industry, in certain cosmetics and in dietary supplements (Uhlig, 1998; Walsh, 2002). It is extensively used for meat tenderizing, brewing, baking, as well as for the production of protein hydrolysates (Ketnawa and Rawdkuen, 2011; 
Walsh, 2002). Bromelain has been also used as a folk medicine, a wound healer, anantiinflammatory, and an anti-diarrhea and digestive aid (Bitange et al., 2008; Koh et al., 2006). In this study extraction of bromealin enzyme from four different pineapple wastes and its effect for tenderization of chicken and beef meats were studied.

\section{Materials and Methods}

\section{Extraction of bromelain}

Extraction using deionized water fresh pineapple were taken and washed with water to take off the dust particles, sand and other foreign or Extraneous matter from the fruit. The wastes are taken separately and weighed and is crushed using phosphate buffer with $\mathrm{pH}$ 6.0 in ratio $1: 1.5$. The mixture is filtered twice using same muslin cloth. The filtrate is centrifuged for $15 \mathrm{~min}$ at $10000 \mathrm{rpm}$ to remove all suspended impurities. This is regarded as the crude bromelain enzyme extract.

\section{Purification of crude enzyme}

The crude enzyme thus prepared is further purified by ethanol extraction methods. The extraction was carried out by ethanol $60 \%$ of absolute ethanol was added to the crude extract and kept overnight in refrigeration at 4 ${ }^{0} \mathrm{C}$. The clear solutions were decanted and small leftover near the bottom of the beaker were centrifuged at $8000 \mathrm{~g}$ for $10 \mathrm{~min}$ at 4 ${ }^{0} \mathrm{C}$. The ppt was freeze dried and dissolved in fixed volume of $0.5 \mathrm{M}$ phosphate buffer $\mathrm{pH}$ 7.4 .

\section{Protease activity of Bromelain Enzyme (BE)}

The protease activity of the bromelain extract was determined according to the method in Murachi (1976) using tyrosine as a standard.
The bromelain activity was determined using casein $(1.5 \%, \mathrm{w} / \mathrm{v})$ as a substrate in the presence of cysteine and EDTA at $37{ }^{\circ} \mathrm{C}$ and pH 7.0 for $10 \mathrm{~min}$. After exactly $10 \mathrm{~min}$, the reaction was stopped by adding $3.0 \mathrm{~mL}$ of $5 \%$ $(\mathrm{w} / \mathrm{v})$ TCA. Precipitated protein was removed by centrifugation at $14000 \mathrm{~g}$ for $10 \mathrm{~min}$. The absorbance of the clear supernatant was measured at $280 \mathrm{~nm}$. One unit of protease activity is defined as the amount of enzyme releasing product equivalent to $1 \mu \mathrm{mol}$ of tyrosine $/ \mathrm{min} / \mathrm{mL}$ under the assay conditions.

\section{Physico-chemical analysis of BE treated meat Samples}

The uniform sized chunks of beef and chicken $(3 \times 3 \times 3 \mathrm{~cm})$ were weighed and then sprinkled by a powder of $\mathrm{BE}[0,0.3 \%, 0.7 \%$, $1.0 \%$ and $2.0 \%(\mathrm{w} / \mathrm{w})]$. Six pieces of meat were used for each treatment.

After mixing thoroughly, the chunks of meat were placed in a $50 \mathrm{ml}$ centrifuge tube and then left at room temperature for $60 \mathrm{~min}$ before determining the physico-chemical and quality characteristics

\section{Water-Holding Capacity (WHC)}

WHC was determined according to method used in Wardlaw et al., (1973). Minced meat $(20 \mathrm{~g})$ was placed in a centrifuge tube containing $30 \mathrm{ml}$ of $0.6 \mathrm{M} \mathrm{NaCl}$ and was stirred with a glass rod for $1 \mathrm{~min}$.

The tube was then kept at $4 \pm 1^{\circ} \mathrm{C}$ for $15 \mathrm{~min}$, stirred again, and then centrifuged at $3000 \mathrm{~g}$ for $25 \mathrm{~min}$. The supernatant was measured, and the WHC was expressed in percentage as the following equation:

Volume of $\mathrm{NaCl}$ before centrifuge Volume of naCl after cdentrifuge WHC $(\%)=$-------------------------- X100 


\section{Cooking Yield (CY)}

The treated samples $(10 \mathrm{~g})$ were steamed for 1 min and then cooled at room temperature. The cooked sample was surface-Dried with a filter paper and reweighed using an analytical balance. The cooking yield was calculated by the difference in raw and cooked weights as following:

Cooking Yield $(\%)=$

Weight of cooked chunks

Weight of raw chunks

pH

The $\mathrm{pH}$ value in meat product is very important as it influences other physicchemical properties like WHC, juiciness, tenderness etc. To determine $\mathrm{pH}, 5 \mathrm{~g}$ of the sample were homogenized with $30 \mathrm{ml}$ of chilled distilled water. The $\mathrm{pH}$ values were measured with a digital $\mathrm{pH}$ meter.

\section{Moisture Content}

The $5 \mathrm{~g}$ each of the samples were suspended in $10 \mathrm{~mL}$ of $0.6 \mathrm{M}$ sodium chloride $(\mathrm{NaCl})$ solution for 30 minutes. The weight of the meat was noted. They were placed on a glass plate and heated at $100^{\circ} \mathrm{C}$ for 20 minutes using a hot plate. The weight of the meat after removing moisture was determined. Percentage of moisture content in the meat samples were calculated as:

Percentage of moisture content $=(($ Initial weight - Final weight) / Initial Weight) x 100.

\section{TCA-soluble peptides content and SDS PAGE analysis}

The TCA-soluble peptides content of the samples was measured by the method used in Benjakul et al., Two grams of the samples were weighed and then homogenized with 18 $\mathrm{ml}$ of $5 \%(\mathrm{w} / \mathrm{v})$ TCA for 1 min and kept at $4^{\circ} \mathrm{C}$ for $1 \mathrm{~h}$ before they were centrifuged at $8000 \times \mathrm{g}$ for $5 \mathrm{~min}$. Soluble peptides in the supernatant were measured by using the Lowry method. To visualised the digestion of meat by the $\mathrm{BE}$ the treated samples were kept at RT for $1 \mathrm{hr}$ and homogenised in 5\% SDS solution. It was the centrifuged at $10000 \mathrm{~g}$ for $10 \mathrm{~min}$. The supernatant was subjected to $12 \%$ SDS PAGE by following Laemmli's method, 1970.

\section{Texture profile analysis}

The analysis was carried out by WarnerBratzler shearing force method using the Warner-Bratzler blade. The boneless meat collected from local butcher were kept at -20

${ }^{0} \mathrm{C}$ for two hrs (for easier handling) and cut in rectangular shape with dimension $20 \mathrm{mmX} 30 \mathrm{~mm}$. The samples were treated with $0,0.5 \mathrm{ml}, 1.0 \mathrm{ml}, 2.0 \mathrm{ml}$ of crude BE $(20 \mathrm{mg} / \mathrm{ml}$ protein) and incubated at $35^{\circ} \mathrm{C}$ for $1 \mathrm{hr}$. Three replication each were taken for each groups and average of the three replicates were presented as the shearing force. TA HD plus texture analyser (Stable micro systems, UK) machine with Warner-Bratzler blade as probe was used during the study of the texture profile. The machine setups include pretest speed- $2 \mathrm{~mm} / \mathrm{sec}$, test speed $1 \mathrm{~mm} / \mathrm{sec}$ and posttest speed $5 \mathrm{~mm} / \mathrm{sec}$. The distance measured was $20 \mathrm{~mm}$ and trigger force was $0.05 \mathrm{~g}$. The software Texture Exponent lite was used for analysis.

\section{Results and Discussion}

During the processing of pineapple, different waste parts such as crown, peel, core and stem were released. The waste portions such as the peel, core, stem and crown were $28.07 \%$, $8.81 \%, 2.25 \%$ and $20.76 \%(\mathrm{w} / \mathrm{w})$, respectively (Fig. 1). The characteristics of crude bromelain in form of $\mathrm{pH}$, TSS, total protein content and total activity were studied. The 
TSS of core portion showed the highest value $\left(7^{\circ}\right.$ Brix) and stem and crown indicated $2^{\circ}$ Brix. The maximum $\mathrm{pH}$ value was showed in stem region followed by crown, core and peel. The protein concentration of the samples was determined using the Bradford (1976) method and BSA was used as a standard Crown portion showed the maximum total protein content and bromelain activity of $239 \mathrm{mg}$ and $184.69 \mathrm{umol} / \mathrm{min} / \mathrm{ml}$ respectively. The lowest protein content and bromelain activity were detected at the stem portion (Table 1). The physio-chemical and quality characteristics like water-holding capacity, cooking yield, $\mathrm{pH}$, moisture content and TCA-soluble peptides content of the bromelain enzyme (BE) treated meats were conducted. Four different types of bromelain treatments like $0.3 \%, 0.7 \%, 1.0 \%$ and $2.0 \%$ were studied along with control. In both the meats moisture content, $\mathrm{pH}$, cooking yield and water holding capacity were decreased as the percentage of $\mathrm{BE}$ treatments increased having highest in controlled condition. There was significant reduction in WHC in all treated samples. This may be related to lowering of $\mathrm{pH}$ and moisture content which results in protein reactivity (Table 2 and 3). The TCA soluble peptides content was calculated as the $\mu \mathrm{mol}$ of tyrosine/g of the samples. When the concentration of BE was increased, the TCA soluble peptide contents were also increases. The highest TCA soluble peptide $(798 \mu \mathrm{mol} / \mathrm{g})$ of were observed in the chicken $20 \%$ treated followed by beef $(709 \mu \mathrm{mol} / \mathrm{g}) 20 \%$ treated. The lowest TCA soluble fractions were that of the beef without any treatment with $238 \mu \mathrm{mol} / \mathrm{g}$ (Fig. 2). The texture profile of BE treated meats were also studied which indicates gradual changes in the meat texture with increase of BE concentrations (Fig. 3). Treatment of $\mathrm{BE}$ reduce the shearing force significantly from $6.93 \mathrm{~kg}$ (untreated) to $2.43 \mathrm{Kg}$ when treated with $2.0 \mathrm{ml}$ of BE $(20$ $\mathrm{mg} / \mathrm{ml}$ protein) incubated at $35^{\circ} \mathrm{C}$ for $1 \mathrm{hr}$. Likewise, in beef meat the shearing force reduce gradually from $17.78 \mathrm{Kg}$ to $5.67 \mathrm{Kg}$ in the described method.

Table.1 Characteristics of crude bromelain enzyme extract from pineapple wastes

\begin{tabular}{|l|l|l|l|l} 
Waste parts & \multicolumn{1}{|c|}{$\mathbf{p H}$} & \multicolumn{1}{|c|}{ TSS $^{\circ}{ }^{\circ}$ Brix $)$} & $\begin{array}{c}\text { Total protein } \\
(\mathbf{m g})\end{array}$ & \multicolumn{1}{|c|}{$\begin{array}{c}\text { Total Activity } \\
(\boldsymbol{\mu ~ m o l} / \mathbf{m i n} / \mathbf{m l})\end{array}$} \\
\hline peel & $3.8 \pm 0.4$ & $5 \pm 0.51$ & $135.4 \pm 1.56$ & $96.45 \pm 1.90$ \\
\hline core & $4.1 \pm 0.1$ & $7 \pm 0.74$ & $48.6 \pm 0.79$ & $38.12 \pm 0.85$ \\
\hline stem & $5 \pm 0.3$ & $2 \pm 0.12$ & $31.56 \pm 0.58$ & $12.85 \pm 0.12$ \\
\hline crown & $4.7 \pm 0.4$ & $2 \pm 0.16$ & $239.45 \pm 2.56$ & $184.69 \pm 194$
\end{tabular}

Table.2 Effect of bromelain on $\mathrm{pH}$ of treated sample of meat $(\mathrm{n}=3)$

\begin{tabular}{|c|l|l|}
\hline Bromelain treated (\%) & Chicken & Beef \\
\hline 0 & $6.64 \pm 0.87$ & $6.93 \pm 1.47$ \\
\hline 0.3 & $6.54 \pm 0.55$ & $6.25 \pm 0.85$ \\
\hline 0.7 & $6.11 \pm 0.97$ & $6.29 \pm 0.57$ \\
\hline 1.0 & $6.2 \pm 0.66$ & $5.91 \pm 0.47$ \\
\hline 2.0 & $5.47 \pm 0.53$ & $5.54 \pm 0.43$ \\
\hline
\end{tabular}


Table.3 Effect of bromelain on moisture content of treated sample of meat $(\mathrm{n}=3)$

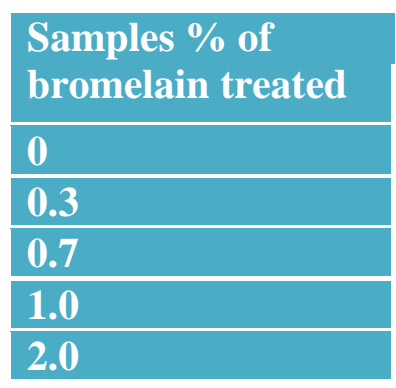

\begin{tabular}{|c|c|}
\hline \multicolumn{2}{|c|}{ Moisture\% $*$} \\
\hline Chicken & Beef \\
\hline 76.8 & 75.44 \\
\hline 72.7 & 71.88 \\
\hline 65.9 & 68.09 \\
\hline 64.77 & 66.75 \\
\hline 60.87 & 65.44 \\
\hline
\end{tabular}

Fig.1 Percentage of different pineapple wastes during processing

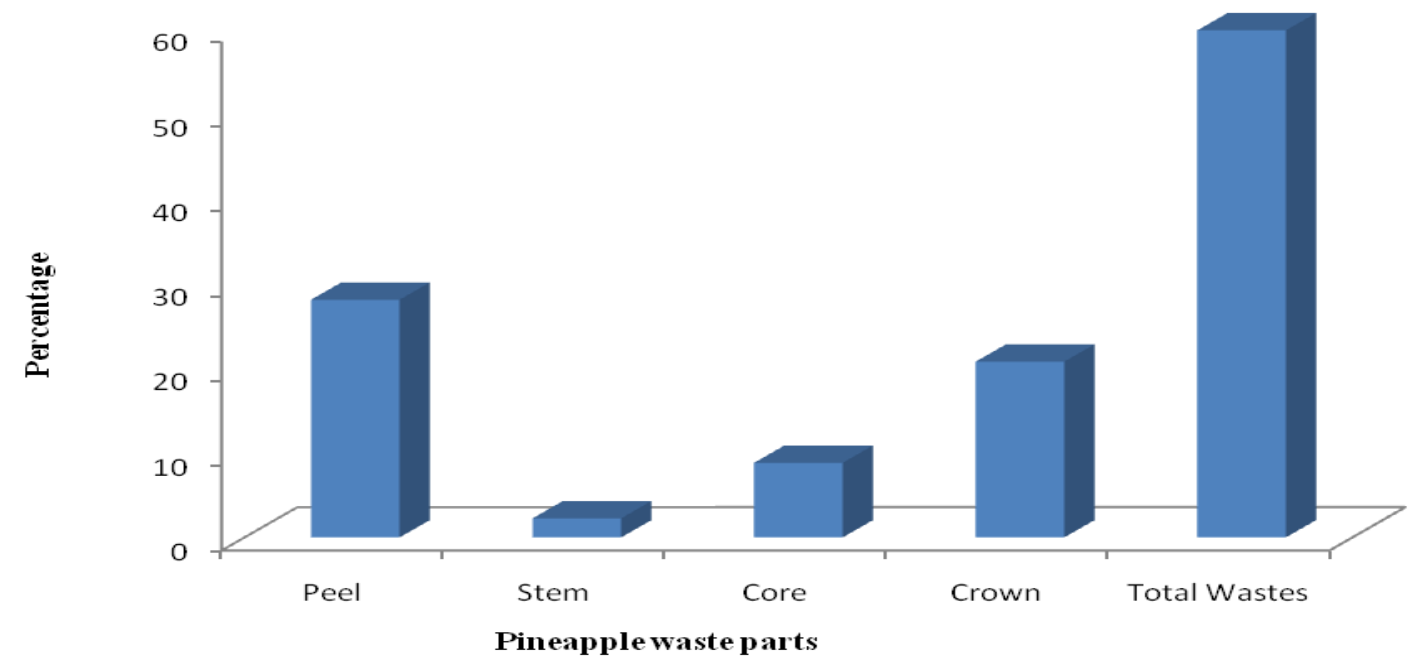

Fig.2 TCA soluble fractions of BE treated fractions

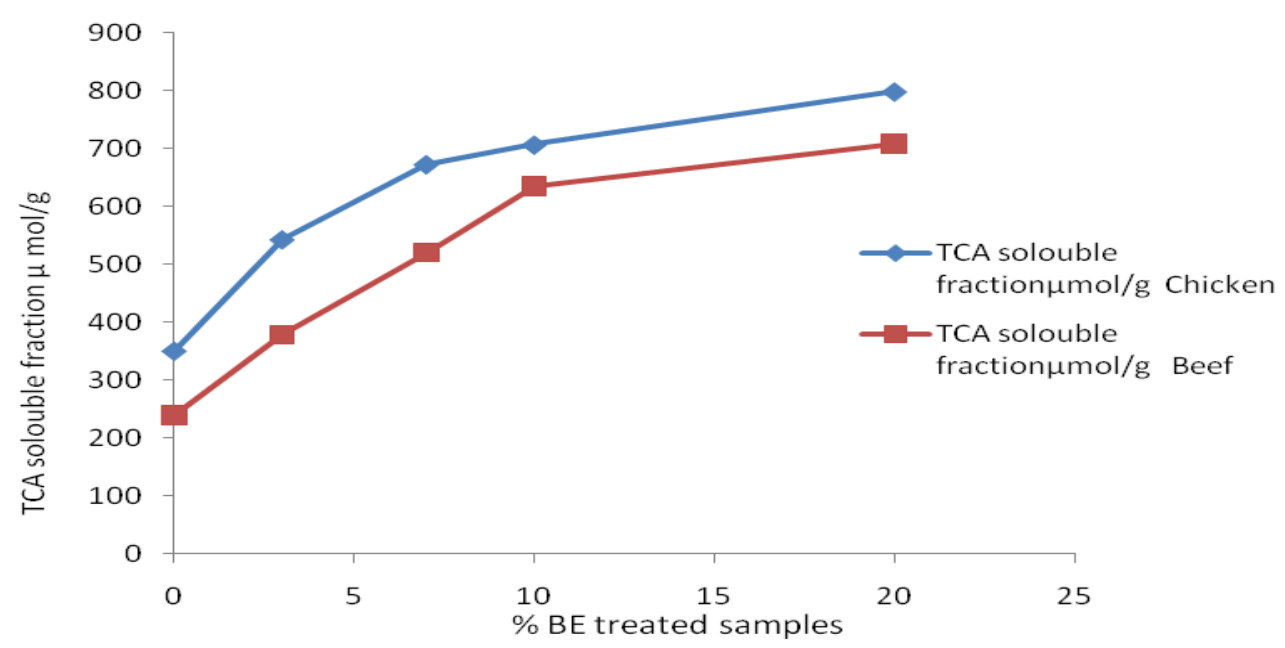


Fig.3 Texture analysis by Warner-Bratzler shearing force: A, Beef; B0, B1, B2, B3 indicates no treatment, 0.5, 1.0, $2.0 \mathrm{ml}$ of crude BE. B, Chicken; C0, C1, C2, C3 indicates no treatment,

$0.5,1.0,2.0 \mathrm{ml}$ of crude $\mathrm{BE}$

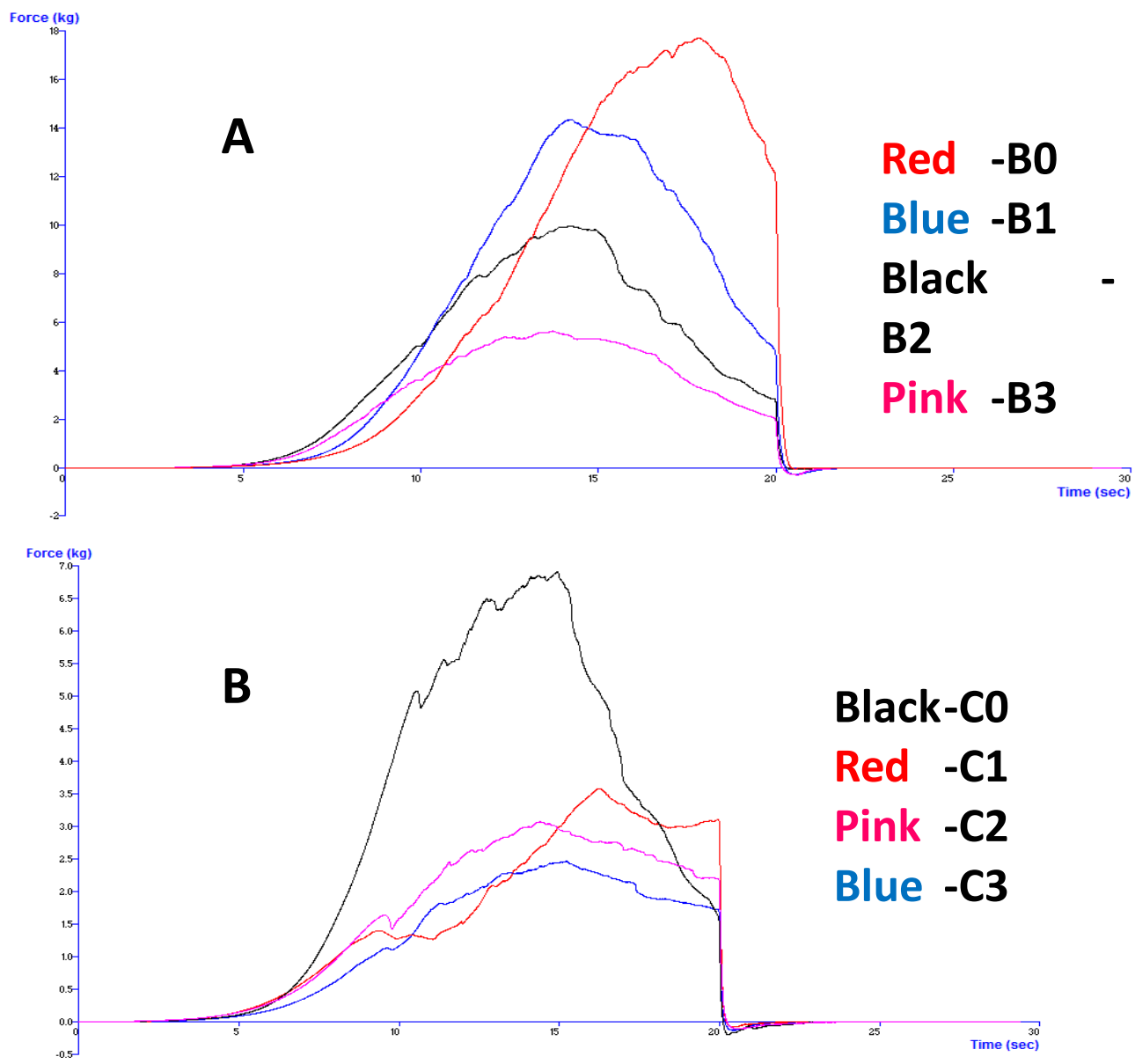

Reverse micellar extraction (RME) was used for the separation and purification of bromelain from pineapple core and efficacy of RME purified bromelain (RMEB) in tenderization of beef meat was compared with that of commercial stem bromelain (CSB) (Chaurasiya et al., 2015) RME resulted in reasonably high bromelain activity recovery $(85.0 \%)$ and purification fold (4.0). Reduction in meat toughness was higher in RMEB treated meat $(52.1 \%)$ compared to raw (control) and CSB treated (26.7 \%). Significant increase in water holding capacity (WHC) was observed in RMEB treated meat $(91.1 \%)$ as against CSB treated $(55.6 \%)$ and control $(56.6 \%)$. But in our investigation, there are no significant changes in WHC between two types of meats. As far the BE treatments were concerned, the controlled condition indicated the highest water holding capacity in both the meats. Another study was conducted by Manohar et al., 2016) for meat tenderising effects of bromelain obtained from pineapple extract. The highest WHC was recorded to be $11 \%$ in the meat sample with the highest concentration of bromelain. The moisture content, too, was analysed and was found to be initially increasing and then decreased when the concentration of bromelain was the highest.

During our study, the crown of pineapple showed the highest proteolytic activity and protein content among the core, stem, and 
peel. The tenderization effects of BE on both chicken and beef were also investigated. Further investigation in this aspect can explore the properties of BE essential for food and pharmaceutical industries. There is great availability of fibre content after the extraction of bromelain from the pineapple wastes. Hence, more research in this sector can evolve some value added compounds having application in industrial field.

\section{References}

Bartholomew, D.P., Paull, R.E., Rohrbach, K.G., 2003. The Pineapple Botany, Production and Uses, vol. 1. CABI publishing, London, pp. 1-29, 281-288.

Bitange, N.T., Zhang, W., Shi, Y.X., Wenbin, Z., 2008. Therapeutic application of pineapple protease (bromelain). Pakistan J. Nutr. 7, 513-520.

Chau, T., David, A.M., 1995. Pineapple waste - a novel substrate for citric acid production by solid state fermentation. Biotechnol. Lett. 17, 1107-1110.

Chaurasiya R S.Sakhare P Z, Bhaskar N, Hebbar H U. 2015 Efficacy of reverse micellar extracted fruit bromelain in meat tenderization. Journal of Food Science and Technology June 2015, Volume 52, Issue 6, pp 3870-3880.

Chen, Q J G. He, H Q, Jiao Y C and Ni, H. "Effects of Elas-tase from a Bacillus Strain on the Tenderization of Beef Meat," Food Chemistry, Vol. 98, No. 4, 2006, pp. 624-629.

Imandi, S.B., Bandaru, V.V., Somalanka, S.R., Bandaru, S.R., Garapati, H.R., 2008. Application of statistical experimental designs for the optimization of medium constituents for the production of citric acid from pineapple waste. Bioresour. Technol. 99, 4445-4450.

Ketnawa, S., Rawdkuen, S., 2011. Application of bromelain extract for muscle foods tenderization. Food Nutri. Sci. 2, 393-401.

Ketnawa, S., Rawdkuen, S., Chaiwut, P., 2010. Two phase partitioning and collagen hydrolysis of bromelain from pineapple peel Nang Lae cultivar. Biochem. Eng. J. 52, 205-211.

Koh, J., Kang, S.M., Kim, S.J., Cha, M.K., Kwon, Y.J., 2006. Effect of pineapple protease on the characteristics of protein fibers. Fiber Polym. 7, 180-185.

Kumar, D., Jain, V.K., Shanker, G., Srivastava, A., 2003. Utilisation of fruits waste for citric acid production by solid state fermentation. Process Biochem. 38, 1725-1729.

Laemmli UK (1970) Cleavage of structural proteins during the assembly of the head of bacteriophage T4. Nature 227: 680685.

Manohar J, Gayathri R, Vishnupriya V. 2016. Tenderisation of Meat Using Bromelain from Pineapple Extract. Int. J. Pharm. Sci. Rev. Res., 39(1), Article No. 17, Pages: 81-85.

Murachi, T., Methods in Enzymology, Lorand L., editions, Vol. 46, pp. 475, (1976).

Neta JLV, DaSilva LA, Lima AA, Santana JC, Leite NS, Ruzene DS, SilvaDP, DeSouza RR. 2012. Bromelain Enzyme from Pineapple: In Vitro Activity Study under Different Micropropagation Conditions. Appl BiochemBiotechnol 168(2): 234-246.

Nigam, J.N., 1999. Continuous ethanol production from pineapple cannery waste. J. Biotechnol. 72, 197-202.

Omojasola, P., Folakemi, J., Omowumi, P., Ibiyemi, S.A., 2008. Cellulase production by some fungi cultured on pineapple waste. Nat. Sci. 6, 64-81.

Pietrasik, Z, Aalhus, J L, Gibson L L and Shand, P J 2010 "Influence of Blade Tenderization, Moisture Enhance-ment and Pancreatin Enzyme Treatment on the Processing Characteristics and 
Tenderness of Beef Semitendinosus Muscle," Meat Science, Vol. 84, No. 3, pp. 512-517.

Rolle, R.S., 1998. Enzyme applications for agro-processing in developing countries: an inventory of current and potential applications. World J. Microbiol. Biotechnol. 14, 611-619.

Schieber, A., Stintzing, F.C., Carle, R., 2001. By-products of plant food processing as a source of functional compounds recent developments. Trend Food Sci. Technol. 12, 401-413.

Smith-Marshall J. Golden KD. Characterization of Bromelain from Morinda citrifolia (Noni). J Sci Res.2012; 4(2): 445-456.

Sunantha Ketnawa, Saroat Rawdkuen, "Application of Bromelain Extract for Muscle Foods Tenderization," Food and Nutrition Sciences, 2, 2011, 393-401.
Tanaka, K., Hilary, Z.D., Ishizaki, A., 1999. Investigation of the utility of pineapple juice and pineapple waste material as low-cost substrate for ethanol fermentation by Zymomonas mobilis. J. Biosci. Bioeng. 87, 642-646.

Thanong, R., 1985. Utilization pineapple waste for frozen pineapple concentrate. J. Kasetsart Univ. 19, 101-109.

Uhlig, H., 1998. Industrial Enzymes and their Applications, vol. 2. John Wiley \& Sons, New York, pp. 146-147.

Upadhyay A, Lama JP, Tawata S. Utilization of Pineapple Waste: A Review. J Food Sci Technol. 2010; 6(1): 10- 18.

Walsh, G., 2002. Protein Biochemistry and Biotechnology, vol. 1.John Wiley and Sons, New York, pp. 51-210, 419-435.

Wardlaw FB, Maccaskill LH, Acton JC. Effect of post mortem muscle changes in poultry meat loaf properties. J Food Sci. $1973 ; 38: 421-424$

\section{How to cite this article:}

Thangjam Anand Singh, Prakash K. Sarangi and Ngankham Joykumar Singh. 2018. Tenderisation of Meat by Bromelain Enzyme Extracted from Pineapple Wastes. Int.J.Curr.Microbiol.App.Sci. 7(09): 3256-3264. doi: https://doi.org/10.20546/ijcmas.2018.709.404 